DOI: $10.1515 /$ hssr -2016-0007

\title{
Between logos and doxa: The Intelligence of a Machine
}

German A. Duarte *

Universidad de Bogotá Jorge Tadeo Lozano, Columbia

\begin{abstract}
This paper deals with Parmenides of Elea's way of inquiry about reality and the opposition emerging from it. In more detail, it analyses how Parmenides' concepts of logos and doxa present some analogies with Bergson's thoughts about duration and Time and how these theories influenced the understanding of visual media, especially the cinematographic camera. This survey will allow us to demonstrate that some scientific theories about space that accompanied the development of the cinematographic camera progressively allowed for the birth of a new understanding of this device. In the last section of this study, we will then focus on the way through which the film camera - understood as an intelligent device - passes from the sphere of doxa to the sphere of logos.
\end{abstract}

Keywords

Media History, Henri Bergson, Philosophy, Non-Euclidean Geometries, Film Studies.

\section{Durée is for doxa}

A large part of ancient philosophical thinking was built on the opposition between logos and doxa. On the one hand, we have the logos ( $\lambda$ ó $о \varsigma)$, a word used by the Greek philosopher Heraclitus and which was understood as the link between discourse and rational structure: logos was

\footnotetext{
* Universidad de Bogotá Jorge Tadeo Lozano, programa de Cine y Televisión, Carrera 4, No. 22- 61 - Modulo 7 - Séptimo Piso, german.duartep@utadeo.edu.co
} 
an objective law, a kind of universal reason. On the other hand, we have doxa $(\delta \dot{o} \xi \alpha)$, a word that denotes common beliefs, people's opinions deriving from pure aesthesis, deriving from a pure phenomenal thought. It would be possible to claim that the conflict between the two terms is the conflict between reason and common beliefs derived from perception.

In Parmenides of Elea's thoughts on motionlessness ( $\alpha^{\prime} \tau \varepsilon \mu \eta \bar{\zeta} \varsigma$ ), a concept developed in his unique surviving work (in fragmentary form), On nature, one can find the conflict between the concepts of logos and doxa. In fact, dealing with the concept of reality ( $\dot{\alpha} \lambda \dot{\eta} \theta \varepsilon \varepsilon \alpha-$ aletheia $\left.^{1}\right)$, in Parmenides' words "what-is", he developed an interesting way of inquiry

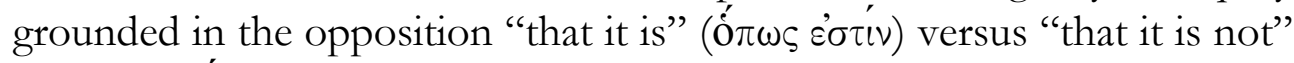
(

"Come now, I will tell thee - and do thou hearken to my saying and carry it away - the only two ways of search that can be thought of. The first, namely, that It is, and that it is impossible for it not to be, is the way of belief, for truth is its companion. The other, namely that It is not, and that it must needs not be, - that, I tell thee, is a path none can learn of at all." (Burnett, 1920: $114(4,5)$ )

Through this opposition, Parmenides places reality exclusively in the logos and not in perception or common beliefs, because, according to him, doxa is misleading. Thus, he theorized an eternal reality which is static and immutable. Given the impossibility of any change of reality, Parmenides also argues that movement is an illusion. Consequently, he asserts that an entity stays always in its place.

Parmenides created a dichotomy between these two ways of investigating reality and the results of his analysis may be summarized as follows:

a) When movement is analyzed through doxa, it exists. However, Parmenides posits that it is an illusion.

b) When movement is analyzed through logos, it does not exist; it is simply impossible.

As one might suppose, Parmenides' theories caused discussions, and 
according to Plato, some philosophers created paradoxes to contradict Parmenides' philosophy. It is possible to imagine that Zeno, being a member of the Eleatic School founded by Parmenides, developed his paradoxes Arguments Against Motion within the crisis generated by Parmenides in order to support his doctrine. In fact, following that an analysis of reality must be effectuated through logos, and arguing that no change is possible, Zeno also concluded that motion is an illusion.

Let us focus more closely on Zeno's arguments, in particular on the Dichotomy Paradox, in which Zeno states that a body in motion that must reach a point $B$, starting from a point $A$, will never succeed. Indeed, the body should first reach the half-way-point of the way. But before reaching this half-way-point, the object would have to reach the half of the half, and before that, the half of the half of the half, and so on to infinity. This recursive operation divides the space to cover an infinite number of times.

Zeno's arguments accomplished his goal of defending Parmenides' thesis. The spatial representation provided by Zeno is inexhaustible. In mathematical terms, it means the impossibility of representing the calculation of this movement, i.e. $1 / 2+1 / 4+1 / 8 \ldots$. Through this paradox, Zeno also argued that due to its being on an infinitely divisible space, the body also needs an infinite time to cover it. Consequently, in this paradox, time is represented by spatial notions, by a geometric line of infinite length. ${ }^{2}$

In the early twentieth century, this same conflict denoted one of the main scientific interests of Bergson's philosophical work. In his work Essai sur les données immediates de la conscience (1889), he theorizes that the analysis of both time and movement follows a kind of juxtaposition with spatial concepts. Let's try to go into a little more detail on the Bergsonian thoughts on movement.

At the end of the nineteenth century, some innovative devices, such as Marey's chronographies and Muybridge's Clock Work Apparatus, were used in the study of movement. Bergson, observing how these devices reproduce movement, focused his attention on the fact that human perception seems to perceive time and movement as divisible entities. This understanding emerges from the simple fact that when one thinks about movement, one is thinking about an object covering a distance. 
According to Bergson, this way of understanding movement and time is essentially an error in the understanding of the nature of movement and derives from its analysis through perception. For Bergson, one should not be able to divide a movement because it is an action. If one tries to divide it, the result would be the creation of two distinct movements. In other words, it necessitates a change of its nature (Deleuze, 1966: 32). Therefore, Bergson posits that movement and time are indivisible entities. Further, according to Bergson, time conceived of as a homogenous entity could be just an incorrect idea caused by the intrusion of some spatial notions. Time conceived as a homogenous, undefined field proves the specter of space in the human cognition of time. Instead, time is an independent entity indivisible in eternal becoming. ${ }^{3}$ Bergson argues that movement is unique; it is a whole action from point $\mathrm{A}$ to point $\mathrm{B}$. If it were possible to mark a point $\mathrm{C}$ between $\mathrm{A}$ and B it would no longer be a unique movement (Bergon, 1907: 309). Therefore, he claims that moving pictures create the same denaturalization of the real entity of movement that Zeno created in his paradoxes. In Bergson's words:

Or, en y réfléchissant davantage, on verra que les positions successives du mobile occupent bien en effet de l'espace, mais que l'opération par laquelle il passe d'une position à l'autre, opération qui occupe de la durée et qui n'à de réalité que pour un spectateur conscient, échappe à l'espace. ${ }^{4}$

Although Bergson never mentions the concepts of logos and doxa, he did propose the existence of two different ways of analysis, from which derive two different kinds of time: a mechanical time, or duration (durée), and a time of natural things, Time (Temps). The first time, the time of mechanics, of non-organic entities, is the time as it is perceived by human senses. Thus, the reproduction of time and movement as performed by visual media. The second time, le Temps, which corresponds to the time of natural things, is an indivisible and eternal time to which every entity in the cosmos is projected. Further, in order to avoid confusion between these two different concepts, Bergson posits that the concept of duration is in opposition to Time. ${ }^{5}$ These main concepts derive from the apparent homogeneity of time, in other words, 
from mankind's notion of time as corresponding to a homogenous space.

"Or remarquons que, lorsque nous parlons du temps, nous pensons le plus souvent à un milieu homogène où nos faits de conscience s'alignent, se juxtaposent comme dans l'espace, et réussissent à former une multiplicité distincte."

Bergson placed Zeno's paradoxes in the technological context of the late nineteenth century, at a time when the perception of nature was completely different from that developed by the Greek philosophers of the fifth century B.C. Within the ideological construction of the Christian era, and especially with the recognition of the presence of God in the world, nature becomes one of the products of creation, something which has a beginning - the Creation Day - and an end - the Last Judgment. In this sense, nature is a gift from God to humanity, and humanity can use it. Then, in the modern age, when humanity recognized its epistemological imperfection, the understanding of nature was completely transformed. At that point in time, science and technology acquired the role of instruments to approach God. In particular, technology began to be used in the investigation and transformation of nature. More importantly, technology began to play the role of the "objective translator" of nature. ${ }^{7}$ As an extension of human senses, technology starts to represent an entity placed in between the object and the subject. Thus, it began to provide humanity an image of "reality": it created a "reality".

\section{Visual media: a reverie on movement}

Visual media were developed within the frame of Euclidean geometry, which is a geometry that simulates human perception and assigns to the geometrical space the characteristics of the space as it is perceived by human cognition, as it is perceived through sight. Thus, when visual media, being the heirs of Euclidean geometry, provide a translation of nature, they provide a pure Euclidean translation. That is to say, a translation that corresponds to our natural perception of space. Either through their scientific origin, or due to their ability to extend the 
capabilities of the sense of sight, visual media have always been seen as objective translators of nature. They were seen as instruments for overcoming the epistemological weakness of mankind. Indeed, visual media allow us to see what is not visible and thus, they allow the establishment of a relationship with a reality existing outside the reach of natural human perception. Yet, as Euclidean geometry is based on human perception of space, it would be impossible to state that the representation of reality, of our space, is a representation completely placed in the sphere of logos. Even if Euclidean geometry is an axiomatic system, a system that can establish a direct correlation with mathematics - thus, apparently, in the middle of reason - it is a geometry based on the limited three-dimensional space perceived by our sense of sight, and also by the film camera. In fact, as a direct heir of the camera obscura, the cinematographic camera is a visual medium directly linked to Euclidean geometry. ${ }^{8}$ Consequently, the film camera, as a technology, is an extension of our sense of sight and offers to us a vision of reality that corresponds to our perception. In other words, the film camera is theoretically unable to produce an image that does not correspond to our natural perception, and is thus unable to approach reality through logos. Just as with human cognition, the film camera projects time upon space.

Like Zeno's paradoxes, which juxtapose space and movement, and grant the nature of space, which is divisible, to movement, which is an action and consequently indivisible, similarly, the film camera exerts the same juxtaposition, offering an image of a fragmented movement and a fragmented time through immobile cuts (coupes immobiles). This is precisely the phenomenon that caught Bergson's attention.? According to Bergson, the examination of time is based on a geometrical figure derived from that projection. The problem arises when that geometrical figure represents a thing and not a progression (Bergson, 1889: 84). In fact, when the time is up, it is impossible to represent the successive moments as external to each other and think of a line through space. However, it is understood that that line represents not the flow of time but its expiration. This line, which creates some spatial notions in the analysis of time and movement, is just a symbol of time and is unable to manifest the state of becoming. Hence, time and movement can be represented in space but only as expired actions; flowing time cannot be 
represented in space (Bergson, 1896: 213). Bergson concludes that a mathematical symbol able to express the essence of movement does not exist because these symbols, always intended to measure, are only able to express distances.

Certainly, these thoughts were influenced by the vision of "decomposed movement" generated by means of Muybridge and Marey's techniques. Bergson saw, in Marey's photographic fusil, not only an instrument that allowed a new perception of movement but also an instrument that highlighted humanity's process of perception of time and movement. In fact, the images generated by Marey's photographic fusil amalgamates time and space because each frame corresponds to a precise "time", which is strictly correlated to a precise spatial notion. However, it is important to remember that for Marey movement was a moment to synthesize by keeping the notion of one point of view. In other words, Marey was interested in keeping the 'unity' of movement. This differs from what Muybridge did on the other side of the Atlantic by using many different cameras. This is the reason why one can say that Marey reproduced "motion as a spatio-temporal continuum. Condensed through the lens of a single camera." (Zielinski, 1999: 58)

With Marey's method, time becomes a "sculpture". The dimension of time developed by Marey shows a kind of elasticity of the body in movement. The single point of view, developed by Marey using the photographic fusil, started to move away, in a sense, from Zeno's ideas of movement. Even if the photographic fusil applied the same logic as Zeno, the fluidity of movement, and the elasticity acquired by the represented bodies in movement, started being perceived as the transformation of space and not as the distance covered by the object. Consider, for instance, the conceptual opposition that Merleau-Ponty highlighted between Marey's and Muybridge's methods. On the one hand, there is the reproduction of movement, understood as the passage of the object through different spaces: in Merleau-Ponty's words, "une reverie zénonienne sur le movement." On the other hand, one is developing the method of sculpture. Borrowing from Merleau-Ponty:

Le cinéma donne le mouvement, mais comment? Est-ce, comme on croit, en copiant de plus près le changement de lieu? On peut présumer que non, 
puisque le ralenti donne un corps flottant entre les objets comme une algue, et qui ne se meut pas. Ce qui donne le mouvement, dit Rodin, c'est une image où les bras, les jambes, le tronc, la tête sont pris chacun à un autre instant, qui donc figure le corps dans une attitude qu'il n'a eue à aucun moment, et impose entre ses parties des raccords fictifs, comme si cet sur la toile la transition et la durée. ${ }^{10}$

Let's focus a little more on Marey's interest and background. Marey went to Paris in 1849 to study medicine and ten years later obtained his doctorate degree with a thesis on the circulation of blood. ${ }^{11} \mathrm{He}$ became a well-known physiologist (un ingenieur de la vie). His main idea was that animals and of course also humans must be analyzed as machines (see Marey, 1873). This conception of life - not so different from Bacon's idea that allowed for the exteriorization of sight by means of the camera obscura - allowed Marey to start researching the inner movements of humans and animals by means of some machines which translated natural movement into mechanical concepts. His aim was to achieve, with physics-like precision, an analysis of biological phenomena, primarily movement, or as he defined it: "the most important act." According to Marey, movement was a translation of all phenomena of life and its analysis implied its comprehension in time. In other words, life was a coordination of functions that could be analyzed as a multifarious mechanical apparatus coordinated in harmony. Thus, Marey's idea of physiology was based on the comprehension of successive states of the body in time. Hence, photographic technology became an important instrument for Marey's research.

Photographic technology arrived some years later in Marey's works, in 1882. This technology represented for Marey just a means which allowed for the improvement of his earlier works. ${ }^{12}$ The influence of Muybridge's works is clear. In fact, in 1881 Marey met Muybridge in Paris and asked him to obtain some photographs of birds. Marey was disappointed with Muybridge's photos and decided to obtain some himself. The success of Janssen's photographic revolver inspired Marey to improve upon the photographic revolver used to watch the passage of Venus some years earlier. Marey's aim was to take a photograph of the movement of the wings of a flying bird, that is to say, not only of the animal accomplishing the aerial movement, but also to divide the beat of the wings. When 
Marey decided to work on the improvement of Jansenn's revolver, he was aiming to invent a portable machine able to take a series of instantaneous pictures separated by short intervals.

Il fallait donc modifier la méthode et construire un appareil simple, portatif, au moyen duquel on pût, sur un oiseau volant en liberté, prendre une série d'images photographiques instantanées, à des intervalles de temps assez courts pour que plusieurs images consécutives correspondissent aux phases successives d'un même battement d'aile. ${ }^{13}$

Designed as a real gun, the device was engineered with a lens in the barrel and a cylinder head on which turned the photographic plate when one pressed the trigger. The rotating plate was round or octagonal, covered by gelatin silver bromide. The plate could stop 12 times per second in front of the lens, while the shutter let light through at 1/720 of a second per shot. The focus was adjusted by extending or shortening the barrel. The same year he developed the chronographe à plaque fixe, in order to better capture on the same plate a series of successive images representing the different positions of a human or animal in locomotion.

Even though the photographic fusil only diverges from the Muybridge method in the one aspect, by using one single camera, the movement reproduced by Marey's device presents a kind of flexibility of the object represented. And maybe that is the reason why Marey started to improve and use this device in the analysis of chaotic movements.

\section{A new notion of space (Marey, Bergson, Poincaré)}

Marey's photographic period is characterized by the vast and exhaustive study of movement in all its forms. The better known of Marey's studies dealt with avian flight, insect flight, human locomotion and animal locomotion (see Marey, 1873). However, he also undertook the analysis of ballistics, acceleration, stereoscopy, hydrodynamics, aerodynamics, and, more important for our subject, hyperboloids, ${ }^{14}$ or the study of objects that create space through their movements. These last studies were developed in the late 1880s and published in his work entitled Le movement 1894. As one can see, in the series of chronographies Marey developed, especially in his chronographie: Mouvements d'un liquide à la 
rencontre d'un obstacle plan (1893), he started to be interested in chaotic movements, movements that escape from the Clockwork Universe Theory. This interest finds an explanation in the need to respond to a new human need embodied by a scientific revolution that found as its first exponent in the scientific field Henri Poincaré, who in 1892 laid the foundations for a critical theory known as topology and the Analysis Situs.

Through the Analysis Situs, Poincaré aimed at creating a space that allowed scientists to explain phenomena through abstractions that made possible a new character of spatial structures that are highly transformative. ${ }^{15}$

Poincaré expressed the need for such a space as follows:

Il faut qu'on arrive à le construire [L'Analysis Situs] des espaces supérieurs; on aura alors un instrument qui permettre réellement de voir dans l'hyperespace et de supplér á nos sens. ${ }^{16}$

What is important to note is that Poincaré's Analysis Situs and topology represented a violent departure from the space built by Euclides and Greek thought (see Serres, 1993). Poincaré's research on space, Bergson theories on space, movement and time, and Marey's moving images show that in that period a new character of space, and consequently of perception, clearly influenced by Leibniz's ideas, was emerging. Certainly the peak of these revolutionary ideas was represented by topology (Günzel, 2007: 17).

Poincaré's theories are placed in a special scientific and social context with respect to the interest in the concept of space. In fact, as noted by Henderson, one of the most important philosophical bases developed by Kant in Kritik der reinen Vernunft is the distinction between synthetic and analytic judgments. Kant argued that there exist judgments that are synthetic a priori and demonstrated their existence by means of axioms of pure mathematics and geometry. Consequently, the a priori nature of the axioms governed Kant's definition of space as a pure form of sensibility. Thus, according to Kant, there is no space with more than three dimensions. Kant's space corresponded to Euclidean space in that it accepted only three dimensions. ${ }^{17}$ The philosophical questions deriving 
from the development of non-Euclidean geometries, especially due to Kant's reflections about space, brought the subject of new geometries and the possible existence of more than three dimensions to the popular sphere. This was the case for Hermann Ludwig Ferdinand von Helmholtz (1821-1894), who tried to popularize the subject to an audience not familiar with mathematics. Helmholtz argued that geometrical axioms vary according to the kind of space inhabited (see Helmholtz, 1876). He theorized a space curvature, from which derives a fourth dimension in space, a property of the space that can be recognized only through analytical calculation. ${ }^{18}$

The geometry that had accompanied mankind through millennia was based on a direct experience of nature, and, consequently, it could only reflect the space in which mankind lives. This notwithstanding, geometry can also be a means of analysis of spaces invented by mankind and derived from abstractions of nature. This phenomenon was highlighted by Poincaré in this words: "[...] Nous avons créé l'espace qu'elle (= la géométrie) étudie, mais en l'adaptant au monde où nous vivons."19 Further, by questioning the universe as seen as a clock, Poincaré started an analysis of movement influenced by Leibniz's Analysis Situs. That allowed him to see movement as the relationships between spaces, as the relationships between points whose links determine movement (see Heuser, 2007). Thanks to this particular approach, Poincaré was able to note the chaotic character of nature, even though he did not define it clearly (see Ekeland, 1995). Thus, thanks to Poincaré, the notion of dimension started to be understood as an instinctive concept built by our ancestors and somehow implanted in our childhood. And it was, in my opinion, this doubt, this suspicion that by way of Euclidean geometry mankind had "implanted" or "programmed" human perception, which accompanied very closely the theories and the invention of devices we are dealing with in this paper.

To come back to Marey, as noted above, his chronographies incline us to think that his interest was not only focused on the analysis of animal and human locomotion, though they represented for him the primary interest. He extended, towards the end of his life, his interest to the perception of spaces, spaces created through movement and chaotic movements. In this way, he joins the scientific interests of his epoch: the 
questioning of the real nature of space and the real character of movement. It is possible to see these scientific interests as the displacement of the understanding of spaces from the sphere of doxa, represented by Euclidean geometries, to the sphere of logos, embodied by the new geometries and experiences offered by new technologies of vision. Thus, one can see that Marey's works also converge with Bergson's thoughts on positive metaphysics (métaphysique positive) in which Bergson proposes a science based on both imitation and analysis of the "sciences of life", what he called "une théorie toute saturée d'experience." 20 According to Bergson, the acknowledgement of the irregularity of natural movements defines the awareness of a new situation in the history of science. ${ }^{21}$ Thus, Bergson started to highlight that Euclidean geometry, and science in general, exerted a representation of natural forms and phenomena that could be just an allusion to the real phenomenon or form. In other words, he remarks that Euclidean geometry is a science that simulates our perception and thus is unable to present to us a real form of the universe, which one can suppose is very different to the picture one receives by way of our senses.

[L]es phénomènes physiques qui se succèdent et sont perçus par nos sens distinguent par la qualité non moins que par sa quantité, de sorte qu'on aurait quelque peine à les déclarer d'abord équivalentes les uns aux autres. Mais, précisément parce que nos sens les perçoivent, rien n'empêche d'attribuer leurs différences qualitatives à l'impression qu'ils font sur nous, et de supposer, derrière l'hétérogénéité de nos sensations, un univers physique homogène. ${ }^{22}$

However, the recognition of natural irregularity, according to Bergson, passes through all human experience, that is to say, through the perpetual analysis of nature that is subject to changes when science and technology offer to the human intellect any new kind of experience. Consequently, the motion-picture technique represented for Bergson an exact point which links science and metaphysics (see Fihmann, 1999). 


\section{The intelligence of a machine and the fourth dimension}

It was theorized that the simple possibility of technical reproduction in art offered by photographic technology set the discipline of painting free from the search for an objective reproduction of nature. The influence of the theories of non-Euclidean geometries on art movements like cubism shows that it was not only the appearance of photography that allowed artists to represent the world free from Euclidean rules, especially the laws of perspective. As we can see, artists started to represent the world theorized by scientific improvements in geometry. Science and art started to recognize the irregularity of nature as well as the existence of dimensions that cannot be perceived by the human eye. Thus, it would be appropriate to recognize some forms of artistic expression or pictorial representation, such as cubism, as not merely the products of technological improvements, that is to say, as not merely the product of the capacity to reproduce nature with the high degree of objectivity offered by photographic technology. It is possible to theorize that non-Euclidean geometries generated another meaning of human perception that some forms of artistic expression, e.g. cubism, strived to reach. In Apollinaire's words:

Ce qui différence le cubisme de l'ancienne peinture, c'est qu'il n'est pas un art d'imitation, mais un art de conception qui tend à s'élever jusqu'à la création. En représentant la réalité-conçue ou la réalité-créée, le peintre peut donner l'apparence de trois dimensions, peut en quelque sorte cubiquer. Il ne pourrait pas en rendant simplement la réalité-vue, à moins de faire du trompe-l'œil en raccourci ou en perspective, ce qui déformerait la qualité de la forme conçue ou crée." ${ }^{23}$

The new sense of freedom in the arts was based on the capacity to recognize the so-called fourth dimension. Indeed, to recognize the fourth dimension meant to be free from the classical perception imposed by Euclid and, consequently, to set the mind free from the Greek conception of beauty in which man is the measure of perfection. However, the interest of Marey in analyzing chaotic movements and forms created through movement, by means of his photographic fusil, allow us to suppose that he was giving to this machine the faculty of 
discovering something invisible to the naked eye: a fourth dimension. We might suppose that, even if the camera is a copy of the sense of sight, it could be able to escape from our natural perception. In my opinion, it was not only a documentary interest that inspired Marey to make moving pictures of chaotic movements, or hyperboloids. If we go back to the social context that saw the development of the photographic technology and cinematography, one can see that these technologies, perceived as mere extensions of human senses, were also seen as objective translators of reality. However, a reality that corresponded to our natural perception. The camera offered a space in three dimensions and a divisible movement: its image could only correspond to the sphere of doxa. However, the suspicion that the device had its own intelligence was there, the suspicion that the camera could demonstrate a different space, a space developing in the field of mathematics and geometry, a space that found its shape in cubism. It is not a coincidence that many authors understood the film camera as a device able to show a new reality. Consider, for instance, the films and theories of Dziga Vertov, who was influenced by futurism and claimed the supremacy of the machine over mankind. He worshiped mechanics, the beauty of chemical processes and the machine as a supreme masterwork. In Vertov's case, the concept of the fourth dimension was expressed through time. In fact, according to Vertov, the narrative in film was composed of the three Euclidean dimensions inherited by the camera obscura plus the dimension of time (see Vertov, 2011). However, the film camera was still placed in the sphere of doxa. It was seen as a non-biological copy of a biological limitation.

In this paper we dealt with two different ways of approaching reality. The first dichotomy was highlighted by the conflict between logos and doxa theorized by Parmenides. In more recent times, we found that the same conflict was presented by Bergson's concepts of Time and duration. We saw that Bergson's concepts were highly influenced by technological improvements in the field of visual media. At the same time during which these visual media were developed, we could see that a new idea of space, of reality, emerged in the field of science and then in the arts. We saw that in the beginning, the film camera was relegated to the field of doxa. It offered only an image of reality as it is perceived by 
the naked eye. But at the same time, we could also see that the idea of a supremacy of the machine, of the camera, over human senses progressively brought some authors and scientists, like Marey and Vertov, to try to depict irregular movements or to "discover", with the camera, a hidden reality. However, if we analyze the early cinematographic images, we can see that they were restricted to reproducing mankind's natural perception. The film camera offered only a fixed shoot, it constructed only a spatial plane. As noted by Deleuze, the evolution of cinema, or the conquest of its essence, was achieved through the mobility of the camera, the montage, and the liberation of the camera from the projection device(Deleuze, 1983: 12). In fact, it is important to remember that Lumière's invention conceived the camera as the projection device. Further, according to Deleuze, the cinematographic technique finds its pre-history not in photographic technology, but rather in instantaneous photography, particularly in the equidistance of the snapshots materialized by the film as a surface and the mechanism that drives the images (Lumière's invention of claws) (Deleuze, 1983: 14). Thus, the film camera represents an entirely new technology, and consequently, a technology with different capacities compared to previous visual media. According to Deleuze, that was the reason why Bergson, even though he already postulated the notion of coupes mobiles in an earlier work, even earlier than Lumière's invention, placed the camera in the field of the natural perception of movement. To follow the terms developed in his paper, Bergson placed the film camera into the sphere of doxa because at the time he was publishing L'evolution créatrice (1907) he only knew fixed images, cinematographic cameras constrained to simulating our natural perception of reality.

The invention of cinematography, realized by the Lumière Brothers in the late nineteenth century, did not respond to an artistic need, but rather it represented both a technological development and a philosophical instrument (see Panofsky, 1974). Indeed, at the time of the first tests of this new technology, Henry Bergson highlighted, in his research on movement, some geometrical connotations and philosophical theories that could derive from the Lumière brother's brilliant invention. Despite this, the hypotheses proposed by Bergson were quickly eclipsed, in the field of film analysis and critique, by the 
advance of formalist theories presenting the Saussurian matrix. Moreover, Bergson had given to moving images geometrical connotations, which completely opposed the assimilation of film as a language that structuralism attempted to impose on the study of film narratives. It was as if the influence of theater and literature on film had imposed an obsessive search for a grammar of film narrative, prejudicing a kind of geodesic understanding of filmic images. However, some authors, like Jean Epstein, escaped from the cage created by structuralism and continued to support the thesis that the cinematographic image is closer to a geometrical system than a kind of grammar. Further, the cinematographic image that Epstein dealt with was already a moving image: it was an image-mouvement. Consequently, according to Epstein, the assimilation of cinema as a language was misleading because the film camera essentially offers to human cognition the possibility of a new spatial perception, one might say, a space closer to logos. And this is precisely what Jean Epstein posited in his work L'intelligence d'une machine (1946). In this book, Epstein understands film as a spatial organization directly derived from a kind of geometrical order developed by the film camera. According to Epstein, the camera, with its own intelligence, creates a special space where the hierarchy of natural things no longer exists. Further, with a film camera, movement is not perceived as a human mind naturally perceives it, as an object covering a distance in space. Hence, this kind of perception of movement, exclusively allowed by the cinematographic camera, allowed Epstein to posit that the film camera was an instrument that exerted a "désarticulation de la nature" and, further, he described film space as a space where:

les chevaux planent au-dessus de l'obstacle ; les plantes gesticulent ; les cristaux s'accouplent, se reproduisent, cicatrisent leurs plaies ; la lave rampe ; l'eau devient huile, gomme, poix arborescente ; l'homme acquiert la densité d'un nuage, la consistance d'une vapeur ; il est un pur animal gazeux, d'une grâce féline, d'une adresse simiesque. Tous les systèmes compartimentés de la nature se trouvent désarticulés. Il ne reste plus qu'un règne : la vie. ${ }^{24}$

The film camera's ability to destroy the dogma of life's irreversibility represented for Epstein an important factor requiring a lengthy analysis 
that positioned the understanding of cinematographic narrative into the field of geometry instead of the field of linguistics. According to Epstein, the absence of the principle of entropy in the filmic space represented not only a narrative tool but also an instrument of analysis of life: an instrument that allowed the confrontation of our cognition with new phenomenological inputs. More importantly, the film camera allowed the depiction of the space that was emerging in the scientific field thanks to new theories, theories that proposed a different nature of space and, consequently, reality. Thus, the art of film represented a philosophical instrument while offering a new way to analyze nature and society. Epstein's analysis starts, therefore, to highlight the film's capacity to offer a break between the movement perceived as an object covering a distance in space, and the movement perceived as an act transforming the space. And that was precisely what Bergson theorized before knowing Lumière's invention in Matière et mémoire, published in 1896. As noted above, it is possible that the first moving images gave Bergson the idea that the film camera was a simple device that simulates human natural perception, and indeed that idea does correspond to the first moving images. Maybe that is the reason why neither Marey nor Lumière believed in the potentialities of the camera.

By granting the film camera its own intelligence, Epstein started to realize that this device was able to show us a different reality, a reality which corresponded to non-Euclidean geometries. Certainly, the film image could do that, and started to do it after the Second World War. That is to say, film narratives started to escape from the sphere of doxa. The film camera started to show the world that science had theorized. They started to show a reality placed in the logos. Almost a half-century later, when video technology was at its peak and digital technology was emerging from the scientific sphere, Gilles Deleuze proposed a study of film history focused on the narrative spatial constructions of the film image. By arguing that Bresson creates a Rimannian Space as well as Neo-Realism and La Nouvelle Vague, by analyzing Robbe-Grillet's narrative constructions as a Quantum Space and Resnais's narratives as Topologic Space, Deleuze not only marked the end of structuralist influence in film analysis, but also demonstrated that for decades the film camera had been showing to mankind spaces coming from human 
reason, ${ }^{25}$ spaces that do not correspond to our common beliefs or our common perception of reality, spaces coming from logos.

\section{References}

Apollinaire, G. (1965). Les peintres cubistes, Paris: Miroirs de l'Art, Hermann. Bachelard, G. (1932). L'intuition de l'instant, Paris: Stock.

Bacon, R. (1928). The Opus Majus of Roger Bacon. 1 vol. Ed. R.B. Burke. Philadelphia - London: University of Pennsylvania Press.

Bergson, H. (1889). Essai sur les données immédiates de la conscience. Paris: F. Alcan. Bergson, H. (1896). Matière et mémoire. Paris: F. Alcan.

Bergson, H. (1907). L'evolution créatrice. Paris: F. Alcan.

Burnet, J. (19203). Early Greek Philosopby. London: A\&C Black Ltd..

Dantzig, T. (1954 ). Number, The Language of Science. Toronto: Plume.

Deleuze, G. (1966). Le bergsonisme. Paris: PUF.

Deleuze, G. Cinéma 1. (1983). L’image-mouvement. Paris: Les éditions de minuit.

Deleuze, G. Cinéma 2. (1985). L'image-temps. Paris: Les éditions de minuit.

Dieudonné, J. A. (1989). History of Algebraic and differential Topology 1900-1960. Boston, MA and Basel: Birkhäuser.

Eco, U. (2003). Dire quasi la stessa cosa. Esperienze di traduzione. Milano: Bompiani. Epstein, J. (1946). L'intelligence d'une machine. Paris: Melot.

Ekeland, I. (1995). Le Chaos. Paris: Flammarion.

Fihman G. (1999). "Bergson, Zénon d'Élée et le cinéma /Bergson, Deleuze und das Kino." Der Film bei Deleure / Le cinéma selon Deleure. Eds. O. Fahle and L. Engell. Weimar: Verlag der Bauhaus-Universität Weimar. 62-85.

Günzel S. (2007). "Raum - Topographie - Topologie." Topologie. Zur Raumbeschreibung in den Kultur- und Medienwissenschaften. Ed. S. Günzel. Bielefeld: Transcript Verlag. 13-29.

Heidegger, M. (1954). Vom Wessen der Wabrheit. Frankfurt am Main: Vittorio Klostermann $\mathrm{GmbH}$.

Henderson, L.D. (1983). The Fourth Dimension and Non-Euclidean Geometry in Modern Art. New Jersey: Princeton University Press.

Helmholtz H. (1876). "The Origin and Meaning of Geometrical Axioms." Mind 1/3 (Jul. 1876): 301-321.

Heuser, M.-L. (2007). "Die Anfänge der Topologie in Mathematik und Naturphilosophie." Topologie. Zur Raumbeschreibung in den Kultur- und Medienwissenschaften. Ed. S. Günzel. Bielefeld: Transcript Verlag. 181-200.

Marey, E.J. (1863). Physiologie médicale de la circulation du sang, basée sur l'étude des 
mouvements du cour et du pouls artériel, avec application aux maladies de l'appareil circulatoire. Paris: Delahaye.

Marey, E.J. (1873). La machine animale, locomotion terrestre et aérienne. Paris: Librarie Germer Baillière et $C^{\text {ie }}$.

Marey, E.J. (1890). Le vol des oiseaux. Paris: G. Masson.

Merleau-Ponty, M. (1964). L'cil et l'esprit. Paris: Gallimard.

Panofsky E. (1974). "Style and Medium in the Motion Pictures." Film Theory and Criticism: Introductory Readings. Eds. G. Mast and M. Cohen. New York: Oxford University Press.

Poincaré, H. (1908). Science et Méthode. Paris: Flammarion.

Serres, M. (1993). Les origines de la géométrie. Paris: Flammarion.

Steffends, B. (2007). Ibn al-Haytham First scientist. North Carolina Greensboro: Morgan Reynolds Pub.

Vertov, D. (2011). L’Occhio Della rivoluzione. Scritti dal 1922 al 1942. Ed. P. Montani. Milano: Mimesis.

Zielinski, S. (1999). Audiovisions, Cinema and Television as entractes in History. Amsterdam: Amsterdam University Press.

${ }^{1}$ It is important to recall Heidegger's thoughts on the Greek concept of Aletheia $(\dot{\alpha} \lambda \dot{\eta} \theta \varepsilon 1 \alpha)$. Heidegger translates this Greek concept as Unverborgenheit, indicating the state of not being hidden, of being evident. See Heidegger, 1930. ${ }^{2}$ See Dantzig, $1954^{4}$.

${ }^{3}$ It is possible to note the same conception in Leibniz's theory of monadology. In fact, the established harmony of each monad and their relationship in the arrangement is the product of the action of an absolute and universal time in which the perfect concordance of monads can be expressed. See Bachelard, 1932.

4 "Now, if we reflect further, we shall see that the successive positions of the moving body really do occupy space, but that the process through which it passes from one position to the other, a process which occupy duration and which has no reality except for a conscious spectator, eludes spaces." (H. Bergson. (2001). Time and Free Will. An essay on the Immediate Data of Consciousness. Dover Publications Inc., Mineola, New York. 110-111; original edition: Bergson, 1889: 82)

${ }^{5}$ It is important to remember that Duration, in Deleuze's words, is a 'passage' a 'change', a 'becoming', it is a becoming that is prolonged. See Deleuze, 1966.

6 "Now, let us notice that when we speak of time, we generally think of a homogeneous medium in which our conscious states are ranged alongside one 
another as in space, so as to form a discrete multiplicity." (H. Bergson. (2001). Time and Free Will. An essay on the Immediate Data of Consciousness. Dover Publications Inc., Mineola, New York. 90; original edition: Bergson, 1889: 67).

${ }^{7}$ Here I understand the word 'translation' in the meaning given to the term by Umberto Eco. That is to say, as "traduzione di un segno in un altro sistema di segni" (translation of a sign into another system of signs) See Eco, 2003: 277.

${ }^{8}$ For further reading on this development see Bacon, 1928 and Steffens, 2007.

${ }^{9}$ In an interview published in 1914, Bergson expressed the importance of cinematographic technology to the philosophical field. "Il est évident que cette invention, complètement de la photographie instantanée, peut suggérer des idées nouvelles au philosophe." (Georges Michel M. (1914). "Henri Bergson nous parle du cinéma". Le journal. 20 février.)

10 "Cinema portrays movement, but how? Is it, as we are inclined to believe, by coping more closely the changes of place? We may presume not, since slow motion shows a body being carried along, floating among objects like seaweed, but not moving itself. Movement is given, says Rodin, by an image in which the arms, the legs, the trunk and the head are each taken at a different instant, an image which therefore portrays the body in an attitude which it never at any instant really held and which imposes fictive linkages between the parts, as if the mutual confrontation of incompossibles could - and alone could - cause transition and duration to arise in bronze and canvas." (G. Johnson - M. Smith (eds.), The Merleau-Ponty Aesthetics Reader. Philosophy and Painting. Northwestern University Press, Evaston (Ill.), 1993, 121-149, esp. 144-145; original edition: M. Merleau-Ponty, 1964: 79).

${ }^{11}$ His first publication in 1863 was influenced by his studies at the university on blood circulation. See Marey, 1863.

12 As a supplement to his work Méthode graphique he published in 1885 Dévelopement de la méthode graphique par l'emploi de la photographie. In this supplement he explained his interest in photographic technology: "J'ai cherché dans l'emploi de la photographie la solution de certains problèmes qui échappaient aux procédés d'inscription mécanique des mouvements."

13 "It was therefore necessary to modify the method and to develop a simply and portable apparatus, with which we could take, on a free flying bird, a set of instantaneous photographic images at time intervals short enough to ensure that several consecutive images correspond to consecutive phases of the same wingbeat." (E.J. Marey, 1890: 132 [My translation]).

${ }^{14}$ The hyperboloid is a geometric object generated by means of the movement of a rotation on its axis of a hyperbola.

${ }^{15}$ On the development of the Analysis Situs, see Dieudonné, 1989. Especially 
The Work of Poincaré.

16 "We must succeed in constructing it [i.e. the analysis situs] completely in the higher spaces, as we shall then have an instrument which will enable us really to see into hyperspace and to supplement our senses." (H. Poincaré. (2009). Science and Method, Cosimo Classics. New York, 2009. 44; original edition: H. Poincaré, 1908: 40).

${ }^{17}$ See, in general, Henderson, 1983.

${ }^{18}$ See Helmholtz, 1876. It is interesting to note that the popularization of nonEuclidean geometries was specially focused on the existence of a fourth dimension in space. Certainly, this subject was the most interesting for the public. In fact, it was perceived as a weakness of human senses from which derive a kind of illusion of the space in which humans live. In other words, it was understood as the human inability to see reality as well as the existence of an illusion generated by human cognition. Consequently, some literary works like Flatland (1884) by Edwin Abbott Abbott received huge public interest as well as the interest of artists like Duchamp and some Cubists. Theories about a fourth dimension were also the source of many science fiction works, for example, some tales from H.G. Wells. For further information about this subject, see in general Henderson, 1983.

${ }^{19}$ Poincaré, 1908: 121. "(that) we have created the space it (i.e. geometry) studies, but adapting it to the world in which we live."

${ }^{20}$ See Bulletin de la société française de philosophie. 2 mai. 1901. 59.

${ }^{21}$ See Bergson. (1889). Especially La durée réelle et la casualité. 150-163.

22 "On the contrary, physical phenomena, which succeeded one another and are perceived by our senses, are distinguished by quality not less than by quantity, so that there would be some difficulty at once declaring them equivalent to one another. But just because they are perceived through our sense organs, we seem justified in ascribing their qualitative differences to the impression which they make on us and in assuming behind the heterogeneity of our sensations, a homogeneous physical universe." (H. Bergson. (2001). Time and Free Will. An essay on the Immediate Data of Consciousness. Dover Publications Inc., Mineola, New York . 204-205; original edition: Bergson, 1889: 154).

23 "The difference between Cubism and earlier painting is that it is not an imitative art, but a conceptual art, which reaches up to the highs of creation. When depicting conceived-reality or created-reality, the painter can obtain a three-dimensional effect, can, so to speak, cubify. He could not do that by just representing seen-reality, unless he resorted to trompe-l'oeil, with foreshortening or perspective, which would distort the quality of the conceived or created 
HSS, vol. V, no. 1 (2016): 113-134

form." (G. Apollinaire. (2004). The Cubist Painters. University of California Press, Berkeley / Los Angeles. 25; original edition: G. Apollinaire, 1965: 5657).

24 " [...] horses hang over the obstacle; plants gesticulate; crystals couple, reproduce, heal their wounds; lava growl; water becomes oil, rubber, tree-like pitch; human being acquires the density of a cloud, the consistency of a vapor; he is a pure gas animal, with feline grace, with simian skill. Every compartmented system of the nature finds itself disarticulated. There is only one kingdom left: life." (Jean Epstein, L'intelligence d'une machine, Melot 1946, p. 6 [My translation]).

${ }^{25}$ Deleuze, 1985: 169.

\section{Biographical note}

German A. Duarte obtained a Ph.D. degree in Media Studies at the RUHRUniversität Bochum and is currently professor of film studies and communication at the University of Bogotá Jorge Tadeo Lazano. His research interests include history of media, film history, cybernetics, cognitive-cultural economy and philosophy. 